\title{
DATA UPDATES IN THE EFFICIENCY MEASUREMENT OF COOPERATIVES IN INDONESIA
}

\author{
Abi Pratiwa Siregar*, Jamhari, and Lestari Rahayu Waluyati \\ Department of Agricultural Economic and Agribusiness, Faculty of Agriculture, Universitas Gadjah \\ Mada, Yogyakarta, Indonesia \\ Correspondence email: abipratiwasiregar@ugm.ac.id
}

Submitted 25 March 2020; Accepted 04 August 2020

\begin{abstract}
ABSTRAK
Pembaruan data merupakan suatu hal mutlak untuk menghasilkan suatu keputusan atau mengambil kebijakan yang valid dan dapat diandalkan. Di bidang koperasi, data yang diperbarui dari waktu ke waktu dapat dimanfaatkan untuk mengukur sejauh mana koperasi menggunakan sumber daya yang ada untuk meraih luaran (output) yang telah ditetapkan. Tujuan penelitian ini adalah: 1) mengetahui penerapan pembaruan data koperasi di Indonesia, dan 2) mengukur efisiensi koperasi di Indonesia. Metode dasar yang digunakan adalah deksriptif, sedangkan metode analisis data yang digunakan untuk mengukur efisiensi yaitu Data Envelopment Analysis (DEA). Data yang digunakan merupakan data sekunder yang berasal dari publikasi Kementerian Koperasi dan Usaha Kecil dan Menegah Republik Indonesia (Kemenkop dan UKM). Hasil penelitian menunjukkan bahwa pembaruan data koperasi di Indonesia telah berjalan secara reguler. Namun demikian, dalam beberapa terbitan publikasi yang ada, masih ditemukan data yang berstatus sangat sementara dan belum diperbarui dengan waktu terkini. Lebih lanjut, ditinjau berdasarkan aspek efisiensi, secara umum koperasi di beberapa wilayah belum menjalankan kegiatannya secara efisien, baik dikarenakan aktivitas yang berjalan belum optimal maupun aktivitas telah melampaui kapasitas optimal.
\end{abstract}

Kata kunci: data envelopment analysis, efisiensi, indonesia, koperasi, pembaruan data

\begin{abstract}
Updating data is an absolute thing to do to produce a decision or make a valid and reliable policy. In the field of co-operatives, data updated from time to time can be utilized to measure the extent to which cooperatives use available resources to achieve predetermined outputs. The objectives of this study were: 1) to find out the application of co-operative data updates in Indonesia, and 2) to measure the efficiency of co-operatives in Indonesia. This study used a descriptive analysis using secondary data from the Ministry of Cooperatives and Small and Medium Enterprises of the Republic of Indonesia's (Kemenkop dan UKM) publication. The results shows that the data update of co-operatives in Indonesia has been running regularly. However, in several published publications, the status was very temporary and has not been updated with the most recent time. Furthermore, based on efficiency aspects, cooperatives in several regions have not run their activities efficiently, either the activities that have not been optimal or activities have exceeded the optimal capacity.
\end{abstract}

Keywords: data envelopment analysis, data update, efficiency, indonesia, co-operative

\section{INTRODUCTION}

Data availability has a strategic role in the development of a country. Planning or policymaking can be more effective/right on target if it is supported by available data. Sirait (2016) contended that data are generated every day and come from multiple sources. In the government sector, data sources can come from the public's feedback 
and responses on the quality of public services.

Sidauruk and Hamdi (2015) stated that basically, data disclosure is part of the right to information. Therefore, if previously, the fulfillment of the right to public information was demand-driven, then hereafter, the government, through an open data policy, change this. The policy made by the government is to open access and provide data or information which is in the public domain. In the management of data and information, eight principles have become a common agreement internationally, including complete, primary, timely, accessible, processable by a machine of any platform, non-discriminatory, no exclusive ownership, and license-free (Retnowati et al., 2018).

In the cooperative sector, generally, data availability is bottom-up. Primary cooperatives communicate their organization's development to secondary cooperatives and regional officials at the district/city level in charge of cooperatives. Subsequently, the information is passed on to regional apparatus at the provincial level, which eventually forms national accumulated data. This process has a consequence; in the case of a region that does not regularly update its data, it will affect the availability of data nationally.

July 12 every year is celebrated as the cooperative's commemoration. At this time, the Ministry of Cooperatives and SMEs deliver a presentation on the development of cooperatives regarding its quantity and quality. However, in the last five years, there have been adjustments. The material presented was in the form of reorientation, rehabilitation, and development policies for cooperatives. The Ministry of Cooperatives and SMEs changed the orientation from quantity to quality of cooperatives, strengthened the cooperative database so that the recorded data are good cooperatives, and finally, the extent of the cooperative capacity improvement. Although three aspects have been covered, there is still one other strategic aspect that has not become the main focus of cooperative parameters, which is the extent to which the cooperatives use their resources in producing output or generally known as efficiency.

A cooperative is a group of people with the same objective of improving welfare. One of the efforts made is developing a business entity. Emphasis on the presence of a group of people is what distinguishes cooperatives from companies that rely on capital. However, to survive and develop over time, cooperatives need to run their businesses efficiently (Siregar et al., 2016). The more efficient a cooperative is, the fewer costs that need to be borne by members, and thus the ability of members to pay increases (Ariyaratne et al., 2000).

Altman (2015) said that efficiency becomes one of the reasons for prospective members to join a cooperative. For instance, in the agricultural sector, it is expected that by joining agricultural cooperatives, the costs borne by farmers in accessing production facilities or marketing their products will be lower. It is because the cooperative accommodates a group of farmers so that the cost per unit of the cooperative becomes lower. On the other hand, Huang et al. (2013) contended that cooperatives that can survive in the globalization era and competition today are those that always improve their efficiency in all of their activities.

Studies on the efficiency of cooperatives have been widely conducted abroad, including cooperative groups (Othman et al., 2014), co-operative banks (Chen et al., 2008), and agricultural cooperatives (Wang et al., 2012). A study conducted by Othman et al. (2014), It is concluded that of the 56 cooperative groups that became the research sample, only 19.6 percent achieved perfect efficiency $(100 \%$ or $1)$. These results indicate that the cooperative group is not operating at a productive or optimal scale.

A study conducted by Chen et al. (2008) concluded that from 2001 to 2006 , the average values of technical efficiency and pure technical efficiency were 0.938 and 
0.992, respectively. In the pure technical efficiency model, 14 out of a total of 24 cooperative banks were inefficient. Therefore, the value of technical efficiency was better than that of pure technical efficiency. Meanwhile, a study by Wang et al. (2012) showed that 14 out of a total of 104 agricultural cooperatives received an operational efficiency value of 1 . Of the total 42 cooperatives, there were 10 efficient vegetable and fruit cooperatives, and of a total of 35 livestock cooperatives, only 12 could achieve operational efficiency.

In Indonesia, cooperative efficiency studies have been carried out, such as those conducted by Siregar et al. (2016) and Budiasih et al. (2019). However, the scope of these studies was still limited to the aspects of provincial and urban areas. The novelties of this current study are: 1) measuring the efficiency of cooperatives in each province in Indonesia, 2) using data over a relatively long period so that it can describe the trend of efficiency (patterns), and, 3) any similar research with the same scope has never been conducted. The objectives of this research are: 1) to determine the application of data updates of cooperatives in Indonesia, and 2) to measure the efficiency of cooperatives in Indonesia.

\section{RESEARCH METHODS}

The research method of this study was descriptive analytics, which described the object under study through data processing to be interpreted so that a conclusion can be drawn. The data used was secondary data of publications of the Ministry of Cooperatives and SMEs from 2000 to 2019. To answer the first objective, the available data was explained descriptively. Meanwhile, for the second objective, Data Envelopment Analysis (DEA) was used. DEA is a non-parametric frontier method that uses a linear program to compute the comparison of output to input ratios for all units being compared in a population. The DEA method aims to measure the efficiency level of the decision- making unit (DMU) relative to similar DMUs in a set of analyzes (Abidin and Endri, 2009). In this study, the DMUs were the cooperatives in each province in Indonesia. The total number of DMUs was 33, with the order of Aceh, North Sumatra, West Sumatra, Riau, Jambi, South Sumatra, Bengkulu, Lampung, Bangka Belitung, Riau Islands, DKI Jakarta, West Java, Central Java, D.I. Yogyakarta, East Java, Banten, Bali, West Nusa Tenggara, East Nusa Tenggara, West Kalimantan, Central Kalimantan, South Kalimantan, East Kalimantan, North Sulawesi, Central Sulawesi, South Sulawesi, Southeast Sulawesi, Gorontalo, West Sulawesi, Maluku, Papua, North Maluku, West Papua.

In connection with the use of data over a long period to show patterns on the efficiency of cooperatives in Indonesia, the data used in the DEA started from 2004 to 2013. During that period, the total province in Indonesia had reached 33. Meanwhile, North Kalimantan as the $34^{\text {th }}$ province was only recorded in the publication of cooperative data in 2014. Therefore, it was not included in the analysis.

For the measurement of efficiency not to be biased, first, the input and output variables must fulfill the basic concept of DEA, in which: they must be positive and in the form of numbers; the input and output variables have an isotonic relationship; the number of DMUs is three times more than the number of input and output variables; and all DMUs have homogeneous variables. In this study, the input variables consisted of the number of members, the number of managers, the number of employees, owner's equity. Meanwhile, the output variables consisted of the business volume and the remaining results of operations.

The next stage was to determine the DEA model. In this study, the measurement of the efficiency of cooperatives in Indonesia used the DEA model of Constant Return to Scale (CRS) and the DEA model of Variable Return to Scale (VRS) with an input orientation approach. The DEA model of CRS is called global technical efficiency (GTE), 
which assumes that each DMU operates at an optimal scale so that every addition of one input unit will result in a proportional and constant increase in output. However, this state is considered to be ideal which is difficult to achieve in the dynamic economic conditions. Therefore, the DEA model of VRS or so-called pure technical efficiency (PTE) is used, which assumes that the proportion of addition of output resulting from adding one unit of input can decrease (decreasing return to scale) or increase (increasing return to scale).

A DMU is said to be totally efficient if each TE and PTE values is one. Subsequently, if the TE and PTE values are known, then the scale efficiency (SE) can be calculated. SE is obtained from the ratio between the TE and PTE values ( $\mathrm{SE}=\mathrm{TE} / \mathrm{PTE})$. Furthermore, input orientation relates to the follow-up that can be carried out by cooperative management. In the input orientation, it is assumed that the manager/management has more control over the input than the output. It indicates that if inefficiency occurs, the cooperative can handle it relatively easily through better input management than output management.

\section{RESULT AND DISCUSSION}

\section{Data Updates of Cooperatives in Indonesia}

The Ministry of Cooperatives and SMEs publish publications on data of cooperatives annually. From 2000 to 2015, the informed data consists of the number of active and inactive cooperatives, the number of members, the number of cooperatives that hold annual member meetings, the number of managers, the number of employees, owner's equity, external capital, and business volume. In addition, starting from 2016 to 2019, data on the number of managers and the number of employees were not available.

As seen from the updating of data, the publication of data on cooperatives of the Ministry of Cooperatives and SMEs consists of final, temporary, and very temporary data. Final data can be found from 2000 to 2010. In the following years, the Ministry of Cooperatives and SMEs still provided a note that the published data remained temporary and/or very temporary. For instance, the recapitulation of data on cooperatives based on the province as of December 31, 2011, although the document had been available since nine years ago if checked at this time (early 2020), the status remained a very temporary figure.

Updating data can be a form of support for the Ministry of Cooperatives and SMEs in developing cooperatives particularly and providing information to the public generally. Both cooperative and social movements, in general, rely on cooperative data published by the Ministry of Cooperatives and SMEs as the ministry that coordinates cooperatives. Among the eight principles of data openness, the phenomenon that occurred in the publication in 2011 did not fulfill the principle of timely.

Another fact is the differences in the way to manage data from one government order to another. From 2000 to 2012, the Ministry of Cooperatives and SMEs publications presented data on cooperatives down to regency and city levels. However, in the following years, data were only available at the provincial level. Furthermore, since the last five years, a Cooperative Registration Number (NIK) policy has been issued as a manifestation of efforts of reorientation, rehabilitation, and development of cooperatives. NIK is translated as a means of confirming the status of cooperatives to synchronize data on active cooperatives from the database as an active indication with data on cooperatives in the field. This policy also has an impact on the publication of data on cooperatives. If previously, information on the number of active, inactive, and total cooperatives were published, then it changes to the number of active cooperatives and cooperatives that have NIK.

At the macro level, one of the indicators of cooperatives on the economy in Indonesia is generally calculated using a percentage on the formation of Gross 
Domestic Product (GDP). The percentage of data is taken from the sales results or the business volume of the cooperatives in one financial year. The differences in the provisions for the publication of data on cooperatives affect the business volume recorded. If it is assumed that in 2019, the publication of data on cooperatives only come from cooperatives that already have a NIK, then there has been a relatively huge decline in business volume in the last five years. At the end of 2015, the business volume of cooperatives in Indonesia reached 266 trillion rupiahs, while on 31 December 2019, it was recorded at 154 trillion rupiahs or decreased by 41.86 percent.

Another fact regarding the updating of data on cooperatives in Indonesia is that in 2016, financial data on cooperatives indicated an anomaly. As seen in Figure 1, there was a highly high leap in 2016, but a highly sharp decline for the following year, including in owner's equity, external capital, business volume, and remaining results of operations. Referring to the Recapitulation of Data on Cooperatives based on Provinces for the 2016 Fiscal Year (very temporary figures from those implementing/reporting RAT), then the owner's equity, external capital, business volume, and remaining results of operations amount to IDR 26,252, IDR 28,231, IDR 67,502, and IDR 2,711, respectively, with units of million rupiah. This figure shows a very large and unlikely number for the conditions of cooperatives in Indonesia at that time. Therefore, attempts to update data need to be taken seriously and sustainably to produce decisions and/or formulate policies that are right on target.

\section{The Efficiency of Cooperatives in Indonesia}

The first step to take when measuring efficiency using DEA is ensuring that the input and output variables meet the basic concepts of DEA, which must be positive and in the form of numbers; input and output variables have an isotonic relationship; the number of DMUs is three times more than that of input and output variables; and all DMUs have homogeneous variables. In this study, the data used were in the form of numbers and all of them were positive; there were no zeros; the input variables used were the number of members, the number of managers, the number of employees, owner's equity, and external capital, while the output variables consisted of business volume and

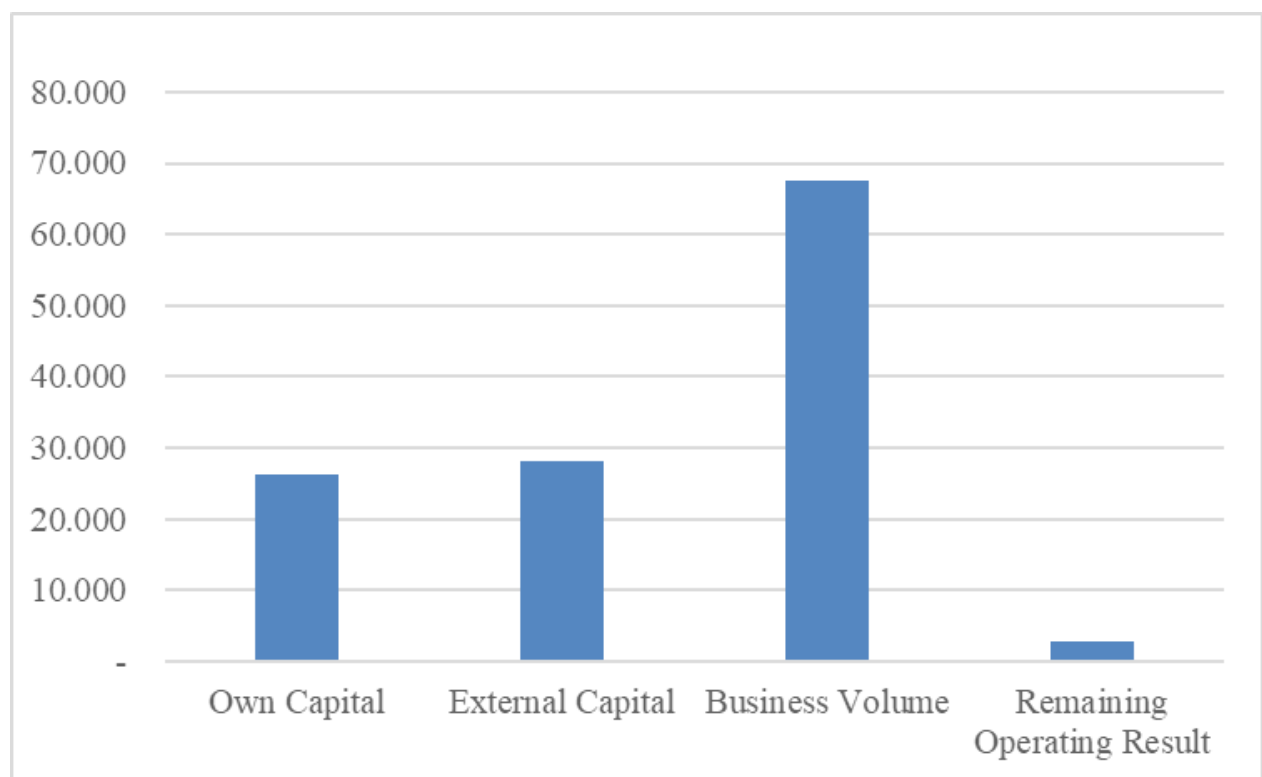

Figure 1. Own Capital, External Capital, Business Volume, and Remaining Operating Results of Cooperatives in Indonesia 2016 (in billions of rupiah)

Source: Kemenkop and UKM (2015 - 2019) 
the remaining results of operations. Between the input and output variables, there was an isotonic relationship, in which if there is an increase in the input variable, there will also be an increase in at least one output variable. Furthermore, the number of DMUs was far more than the total input and output variables
(33 DMU: 6 variables). Therefore, all the basic concepts of the DEA had been fulfilled.

The results of the DEA analysis were scores ranging from zero to one. Number 1 indicated that the DMU was efficient. Conversely, DMU that had a score smaller than 1, was categorized as inefficient. In this study, the measured efficiency was the ability

Table 1. TE Scores of Cooperatives in Indonesia, 2004 - 2013

\begin{tabular}{|c|c|c|c|c|c|c|c|c|c|c|}
\hline \multirow{2}{*}{ DMU } & \multicolumn{10}{|c|}{ TE Score } \\
\hline & 2004 & 2005 & 2006 & 2007 & 2008 & 2009 & 2010 & 2011 & 2012 & 2013 \\
\hline 1 & 0,33 & 0,35 & 0,60 & 0,94 & 0,60 & 0,35 & 0,29 & 0,42 & 0,25 & 0,30 \\
\hline 2 & 0,73 & 1 & 1 & 0,68 & 0,81 & 0,88 & 0,73 & 0,75 & 0,68 & 0,32 \\
\hline 3 & 1 & 0,96 & 0,48 & 0,61 & 1 & 1 & 0,75 & 0,96 & 1 & 0,54 \\
\hline 4 & 1 & 1 & 0,79 & 0,69 & 0,98 & 0,68 & 0,55 & 0,71 & 0,61 & 0,39 \\
\hline 5 & 0,85 & 1 & 0,58 & 0,73 & 0,83 & 0,75 & 0,59 & 0,50 & 1 & 0,70 \\
\hline 6 & 1 & 1 & 1 & 0,83 & 1 & 0,92 & 0,69 & 0,68 & 0,68 & 0,31 \\
\hline 7 & 0,96 & 0,69 & 0,43 & 1 & 1 & 1 & 1 & 1 & 1 & 1 \\
\hline 8 & 0,58 & 0,77 & 0,62 & 0,83 & 0,86 & 0,65 & 0,48 & 1 & 1 & 0,22 \\
\hline 9 & 0,19 & 0,78 & 0,63 & 0,54 & 1 & 1 & 1 & 1 & 1 & 1 \\
\hline 10 & 1 & 0,72 & 0,60 & 0,23 & 0,40 & 0,85 & 0,79 & 0,82 & 0,32 & 0,20 \\
\hline 11 & 1 & 1 & 1 & 1 & 1 & 1 & 1 & 1 & 0,91 & 0,67 \\
\hline 12 & 1 & 1 & 0,62 & 0,49 & 0,74 & 0,96 & 0,94 & 0,80 & 0,57 & 0,35 \\
\hline 13 & 1 & 1 & 0,73 & 0,81 & 0,94 & 0,82 & 0,86 & 0,82 & 0,84 & 0,50 \\
\hline 14 & 0,54 & 1 & 0,71 & 0,74 & 1 & 0,89 & 0,89 & 0,79 & 0,69 & 0,29 \\
\hline 15 & 0,60 & 0,57 & 1 & 0,77 & 1 & 1 & 0,71 & 0,67 & 0,71 & 0,23 \\
\hline 16 & 0,79 & 0,57 & 0,89 & 0,98 & 0,86 & 1 & 0,96 & 0,59 & 0,61 & 0,54 \\
\hline 17 & 0,56 & 1 & 0,78 & 0,82 & 1 & 0,80 & 0,95 & 1 & 0,60 & 0,30 \\
\hline 18 & 0,45 & 0,53 & 0,49 & 0,55 & 0,50 & 0,39 & 0,45 & 0,12 & 0,36 & 0,19 \\
\hline 19 & 0,35 & 0,59 & 0,28 & 0,37 & 0,57 & 0,45 & 0,16 & 0,66 & 0,47 & 0,27 \\
\hline 20 & 0,84 & 0,88 & 0,61 & 1 & 1 & 1 & 1 & 0,77 & 1 & 0,55 \\
\hline 21 & 0,52 & 0,62 & 0,54 & 0,44 & 0,49 & 0,45 & 1 & 0,48 & 0,63 & 0,28 \\
\hline 22 & 0,31 & 0,49 & 0,39 & 0,62 & 0,84 & 0,56 & 0,52 & 1 & 0,73 & 0,38 \\
\hline 23 & 1 & 1 & 1 & 1 & 1 & 1 & 0,98 & 0,93 & 0,58 & 0,26 \\
\hline 24 & 0,78 & 0,84 & 0,29 & 0,20 & 0,14 & 0,32 & 0,28 & 0,06 & 0,11 & 0,05 \\
\hline 25 & 0,33 & 0,33 & 0,22 & 0,21 & 0,22 & 0,18 & 0,26 & 0,35 & 0,51 & 0,18 \\
\hline 26 & 0,62 & 0,84 & 0,68 & 0,43 & 0,39 & 0,93 & 0,76 & 0,40 & 0,53 & 0,24 \\
\hline 27 & 1 & 0,44 & 0,54 & 0,46 & 0,47 & 0,80 & 1 & 0,19 & 0,08 & 0,38 \\
\hline 28 & 0,49 & 0,49 & 1 & 0,57 & 0,54 & 0,44 & 0,48 & 0,50 & 0,33 & 0,18 \\
\hline 29 & 0,71 & 0,69 & 0,68 & 0,41 & 0,31 & 0,56 & 0,72 & 0,67 & 0,51 & 0,45 \\
\hline 30 & 0,48 & 0,39 & 1 & 0,48 & 0,33 & 0,63 & 0,58 & 0,10 & 0,13 & 0,02 \\
\hline 31 & 0,54 & 0,48 & 0,41 & 1 & 1 & 1 & 1 & 1 & 1 & 0,15 \\
\hline 32 & 0,61 & 0,55 & 0,51 & 0,68 & 0,51 & 0,86 & 0,47 & 0,71 & 0,34 & 0,11 \\
\hline 33 & 0,71 & 0,68 & 0,78 & 0,41 & 0,39 & 0,67 & 0,67 & 0,72 & 0,34 & 1 \\
\hline
\end{tabular}

Source: Kemenkop and UKM, 2004-2013 (Processed Data) 
of the DMU to generate output using existing resources. If it reached efficiency, then the DMU could produce its output optimally compared to other DMUs in a set of analyzes. Conversely, it was considered inefficient because based on comparisons with other DMUs in a set of analyzes, the DMU generate outputs that were not yet optimal with existing resources.

The DEA model of CRS produces a score of technical efficiency (TE) with the assumption that the DMU will operate at an optimal scale. Therefore, a proportional change at all input levels will lead to the same proportional change in the output level. Based on the information in Table 1, cooperatives in 33 provinces in Indonesia can be classified into three groups: First, they have never reached efficiency. Second, they are efficient but over time they become inefficient. Third, initially, they are inefficient but becomes efficient.

DEA is called a measure of relative efficiency because it can be compared to the DMU in a set of analyzes only. Therefore, the conclusions about whether cooperatives are efficient or inefficient on the DEA model of the CRS measurement results in Table 1 illustrate how cooperatives in general in a province compare to cooperatives in general in 22 other provinces. Regions that are classified as the first include Aceh, NTB, NTT, North Sulawesi, Central Sulawesi, West Sulawesi, and North Maluku. The second group includes North Sumatra, West Sumatra, Jambi, South Sumatra, Lampung, Riau Islands, DKI Jakarta, West Java, Central Java, D.I. Yogyakarta, East Java, Banten, Bali, West Kalimantan, Central Kalimantan, South Kalimantan, East Kalimantan, Southeast Sulawesi, Gorontalo, Maluku, and Papua. Meanwhile, the third group includes Bengkulu, Bangka Belitung, and West Papua.

The DEA also present the source of the inefficiency of the inefficient DMUs. For instance, in 2013, one of the inefficient DMUs was number 32 with a TE score of 0.11 . Based on the projection results of the DEA, it is concluded that to produce the same output of the business volume of 104,382 (million rupiahs) and the remaining results of operations of 18,188 (million rupiahs), the existing resources (input) can be reduced, including the number of members (88.71 percent), the number of managers $(95.78 \%)$, the number of employees (91.35\%), owner's equity $(90.79 \%)$, and external capital (91.49\%).

DMU number 32 experienced a decline in TE score from 2012 to 2013. It was because of the lower increase in output than the increase in input. In 2012, the number of members, the number of managers, the number of employees, owner's equity, and external capital were $+23 \%,+33 \%,-3.1 \%$, $21 \%$, and $-12 \%$ respectively compared to the input in 2013. However, the business volume actually declined by $145 \%$, and the remaining results of operations were only able to increase by $1.96 \%$.

Krasachat and Chimkul (2009) stated that the DEA model of VRS is more flexible and looks for the minimum point and the maximum point (envelops) more tightly than the DEA model of CRS. Therefore, the PTE score will be equal to or greater than the TE score. Meanwhile, Ramanathan cited in Othman et al. (2014) added that the TE score is not greater than the PTE score because VRS is the composition of the CRS. Therefore, when the VRS assumption is applied, the DMUs, which were initially inefficient in CRS, can become efficient. It is shown in Table 2, in which the number of efficient DMUs according to the DEA model of VRS is more than the DEA model of CRS $(9: 3)$.

Based on the results of the analysis of DEA models of the CRS and VRS, it is known that most cooperatives in Indonesia were relatively inefficient in performing their activities. For instance, DMU number 1 was the inefficient DMU and DMU number 7 was the efficient DMU in 2013. DMU number 1 required the number of members, number of managers, number of employees, owner's equity, and external capital of 500,956 people, 1,720 people, 5,737 people, 398,769 (million 
Table 2. PTE Scores of Cooperatives in Indonesia, 2004 - 2013

\begin{tabular}{|c|c|c|c|c|c|c|c|c|c|c|}
\hline \multirow{2}{*}{ DMU } & \multicolumn{10}{|c|}{ PTE Score } \\
\hline & 2004 & 2005 & 2006 & 2007 & 2008 & 2009 & 2010 & 2011 & 2012 & 2013 \\
\hline 1 & 0,36 & 0,39 & 0,63 & 0,95 & 0,66 & 0,35 & 0,29 & 0,42 & 0,31 & 0,35 \\
\hline 2 & 0,73 & 1 & 1 & 0,82 & 0,81 & 1 & 0,99 & 0,84 & 0,78 & 0,55 \\
\hline 3 & 1 & 0,96 & 0,53 & 0,65 & 1 & 1 & 1 & 1 & 1 & 0,86 \\
\hline 4 & 1 & 1 & 0,86 & 0,70 & 0,98 & 0,73 & 0,61 & 0,79 & 0,63 & 0,40 \\
\hline 5 & 0,95 & 1 & 0,63 & 0,73 & 0,85 & 0,83 & 0,64 & 0,55 & 1 & 0,71 \\
\hline 6 & 1 & 1 & 1 & 1 & 1 & 0,97 & 0,84 & 0,86 & 0,76 & 0,33 \\
\hline 7 & 1 & 0,87 & 0,87 & 1 & 1 & 1 & 1 & 1 & 1 & 1 \\
\hline 8 & 0,60 & 0,77 & 0,63 & 0,84 & 0,92 & 0,84 & 0,52 & 1 & 1 & 0,26 \\
\hline 9 & 1 & 1 & 1 & 1 & 1 & 1 & 1 & 1 & 1 & 1 \\
\hline 10 & 1 & 0,81 & 0,70 & 0,53 & 1 & 1 & 1 & 1 & 0,86 & 0,69 \\
\hline 11 & 1 & 1 & 1 & 1 & 1 & 1 & 1 & 1 & 1 & 1 \\
\hline 12 & 1 & 1 & 1 & 1 & 0,75 & 1 & 1 & 1 & 0,92 & 1 \\
\hline 13 & 1 & 1 & 0,74 & 1 & 0,94 & 0,86 & 1 & 1 & 1 & 1 \\
\hline 14 & 0,63 & 1 & 0,88 & 0,78 & 1 & 0,92 & 1 & 0,91 & 0,78 & 0,31 \\
\hline 15 & 0,70 & 0,72 & 1 & 1 & 1 & 1 & 1 & 1 & 1 & 1 \\
\hline 16 & 0,80 & 0,59 & 0,90 & 0,98 & 0,86 & 1 & 1 & 0,61 & 0,61 & 1 \\
\hline 17 & 0,58 & 1 & 0,81 & 0,82 & 1 & 0,94 & 1 & 1 & 0,76 & 0,88 \\
\hline 18 & 0,49 & 0,55 & 0,56 & 0,58 & 0,51 & 0,45 & 0,53 & 0,23 & 0,38 & 0,25 \\
\hline 19 & 0,40 & 0,64 & 0,38 & 0,45 & 0,64 & 0,47 & 0,24 & 0,66 & 0,48 & 0,30 \\
\hline 20 & 0,91 & 0,96 & 0,70 & 1 & 1 & 1 & 1 & 0,80 & 1 & 0,98 \\
\hline 21 & 0,75 & 0,73 & 0,64 & 0,56 & 0,65 & 0,57 & 1 & 0,69 & 0,63 & 0,50 \\
\hline 22 & 0,41 & 0,58 & 0,47 & 0,65 & 0,92 & 0,57 & 0,55 & 1 & 0,85 & 0,44 \\
\hline 23 & 1 & 1 & 1 & 1 & 1 & 1 & 1 & 0,99 & 0,61 & 0,34 \\
\hline 24 & 0,84 & 0,86 & 0,35 & 0,25 & 0,17 & 0,41 & 0,31 & 0,20 & 0,20 & 0,12 \\
\hline 25 & 0,45 & 0,46 & 0,43 & 0,38 & 0,33 & 0,38 & 0,43 & 0,44 & 0,60 & 0,33 \\
\hline 26 & 0,63 & 0,85 & 0,68 & 0,43 & 0,73 & 1 & 0,78 & 0,68 & 0,74 & 0,39 \\
\hline 27 & 1 & 0,51 & 0,62 & 0,60 & 0,55 & 0,82 & 1 & 0,46 & 0,46 & 1 \\
\hline 28 & 0,89 & 0,87 & 1 & 0,81 & 0,69 & 0,62 & 0,59 & 0,60 & 0,60 & 0,46 \\
\hline 29 & 1 & 0,97 & 0,85 & 1 & 1 & 1 & 1 & 1 & 1 & 0,79 \\
\hline 30 & 0,65 & 0,53 & 1 & 0,67 & 0,62 & 0,68 & 0,60 & 0,54 & 0,53 & 0,26 \\
\hline 31 & 0,65 & 0,62 & 0,60 & 1 & 1 & 1 & 1 & 1 & 1 & 0,37 \\
\hline 32 & 1 & 1 & 1 & 1 & 1 & 1 & 1 & 1 & 1 & 0,76 \\
\hline 33 & 1 & 1 & 1 & 1 & 1 & 1 & 1 & 1 & 1 & 1 \\
\hline
\end{tabular}

Source: Kemenkop and UKM, 2004-2013 (Processed Data)

rupiahs), and 9,979,419 (million rupiahs), 309 people, 1,366 people, 390,736 (million respectively, to produce business volume and rupiahs), and 366,562 (million rupiahs), business results of 1,553,971 (million respectively, in producing business volume rupiahs) and 116,858 (million rupiahs), and remaining results of operations of respectively. Meanwhile, DMU number 7 3,141,929 (million rupiahs) and 142,796 used the number of members, the number of (million rupiahs), respectively. The output managers, the number of employees, owner's produced by DMU number 7 was greater than equity, and external capital of 180,038 people, $202 \%$ (volume of business) and $122 \%$ 
(residual income), using more input but not more than $100 \%$.

After the TE, PTE, and SE scores are known, the next information that can be found is the source of inefficiency, whether it is caused by the operational scale or managerial ability of the DMU management. The value of $\mathrm{SE}<1$ indicates that the DMU inefficiency is because of not operating at a constant rate of return. Meanwhile, the value of PTE $<1$, illustrating that the DMU uses more input than it should (input orientation).

The scale of return among DMUs can be different, but can also be the same, mainly due to the operational level of each DMU, whether it is constant, increasing, or even

Table 3. SE Scores of Cooperatives in Indonesia, 2004 - 2013

\begin{tabular}{|c|c|c|c|c|c|c|c|c|c|c|}
\hline \multirow{2}{*}{ DMU } & \multicolumn{10}{|c|}{ SE Score } \\
\hline & 2004 & 2005 & 2006 & 2007 & 2008 & 2009 & 2010 & 2011 & 2012 & 2013 \\
\hline 1 & 0,92 & 0,90 & 0,96 & 0,99 & 0,91 & 1 & 0,98 & 0,99 & 0,82 & 0,87 \\
\hline 2 & 0,99 & 1 & 1 & 0,83 & 1 & 0,88 & 0,74 & 0,89 & 0,87 & 0,57 \\
\hline 3 & 1 & 0,99 & 0,89 & 0,95 & 1 & 1 & 0,75 & 0,96 & 1 & 0,62 \\
\hline 4 & 1 & 1 & 0,92 & 0,99 & 1 & 0,94 & 0,90 & 0,89 & 0,98 & 0,99 \\
\hline 5 & 0,90 & 1 & 0,92 & 1 & 0,98 & 0,90 & 0,93 & 0,92 & 1 & 0,99 \\
\hline 6 & 1 & 1 & 1 & 0,83 & 1 & 0,94 & 0,81 & 0,79 & 0,90 & 0,96 \\
\hline 7 & 0,96 & 0,79 & 0,49 & 1 & 1 & 1 & 1 & 1 & 1 & 1 \\
\hline 8 & 0,97 & 0,99 & 1 & 1 & 0,93 & 0,77 & 0,92 & 1 & 1 & 0,85 \\
\hline 9 & 0,19 & 0,78 & 0,63 & 0,54 & 1 & 1 & 1 & 1 & 1 & 1 \\
\hline 10 & 1 & 0,90 & 0,86 & 0,44 & 0,40 & 0,85 & 0,79 & 0,82 & 0,37 & 0,28 \\
\hline 11 & 1 & 1 & 1 & 1 & 1 & 1 & 1 & 1 & 0,91 & 0,67 \\
\hline 12 & 1 & 1 & 0,62 & 0,49 & 0,99 & 0,96 & 0,94 & 0,80 & 0,62 & 0,35 \\
\hline 13 & 1 & 1 & 0,99 & 0,81 & 1 & 0,96 & 0,86 & 0,82 & 0,84 & 0,50 \\
\hline 14 & 0,86 & 1 & 0,81 & 0,96 & 1 & 0,96 & 0,89 & 0,87 & 0,89 & 0,95 \\
\hline 15 & 0,86 & 0,79 & 1 & 0,77 & 1 & 1 & 0,71 & 0,67 & 0,71 & 0,23 \\
\hline 16 & 0,99 & 0,97 & 0,98 & 1 & 1 & 1 & 0,96 & 0,96 & 0,99 & 0,54 \\
\hline 17 & 0,97 & 1 & 0,97 & 1 & 1 & 0,85 & 0,95 & 1 & 0,79 & 0,34 \\
\hline 18 & 0,92 & 0,96 & 0,87 & 0,96 & 0,98 & 0,89 & 0,85 & 0,52 & 0,95 & 0,75 \\
\hline 19 & 0,87 & 0,92 & 0,73 & 0,81 & 0,90 & 0,96 & 0,68 & 1 & 0,99 & 0,92 \\
\hline 20 & 0,92 & 0,92 & 0,87 & 1 & 1 & 1 & 1 & 0,96 & 1 & 0,57 \\
\hline 21 & 0,69 & 0,85 & 0,84 & 0,79 & 0,76 & 0,78 & 1 & 0,70 & 0,99 & 0,56 \\
\hline 22 & 0,76 & 0,86 & 0,82 & 0,95 & 0,91 & 0,99 & 0,94 & 1 & 0,86 & 0,87 \\
\hline 23 & 1 & 1 & 1 & 1 & 1 & 1 & 0,98 & 0,94 & 0,96 & 0,78 \\
\hline 24 & 0,93 & 0,98 & 0,83 & 0,82 & 0,83 & 0,77 & 0,90 & 0,28 & 0,55 & 0,44 \\
\hline 25 & 0,74 & 0,71 & 0,51 & 0,55 & 0,65 & 0,49 & 0,60 & 0,80 & 0,85 & 0,54 \\
\hline 26 & 0,99 & 0,99 & 1 & 0,99 & 0,54 & 0,93 & 0,97 & 0,59 & 0,71 & 0,62 \\
\hline 27 & 1 & 0,87 & 0,86 & 0,77 & 0,87 & 0,98 & 1 & 0,41 & 0,18 & 0,38 \\
\hline 28 & 0,55 & 0,57 & 1 & 0,71 & 0,77 & 0,71 & 0,82 & 0,83 & 0,54 & 0,40 \\
\hline 29 & 0,71 & 0,72 & 0,80 & 0,41 & 0,31 & 0,56 & 0,72 & 0,67 & 0,51 & 0,57 \\
\hline 30 & 0,74 & 0,74 & 1 & 0,72 & 0,54 & 0,93 & 0,96 & 0,17 & 0,24 & 0,06 \\
\hline 31 & 0,82 & 0,78 & 0,67 & 1 & 1 & 1 & 1 & 1 & 1 & 0,40 \\
\hline 32 & 0,61 & 0,55 & 0,51 & 0,68 & 0,51 & 0,86 & 0,47 & 0,71 & 0,34 & 0,15 \\
\hline 33 & 0,71 & 0,68 & 0,78 & 0,41 & 0,39 & 0,67 & 0,67 & 0,72 & 0,34 & 1 \\
\hline
\end{tabular}

Source: Kemenkop and UKM, 2004-2013 (Processed Data) 
Table 4. Return to Scale (RTS) DMU, 2004 - 2013

\begin{tabular}{lcccccccccc}
\hline \multirow{2}{*}{ RTS } & \multicolumn{10}{c}{ Years } \\
\cline { 2 - 12 } & $\mathbf{2 0 0 4}$ & $\mathbf{2 0 0 5}$ & $\mathbf{2 0 0 6}$ & $\mathbf{2 0 0 7}$ & $\mathbf{2 0 0 8}$ & $\mathbf{2 0 0 9}$ & $\mathbf{2 0 1 0}$ & $\mathbf{2 0 1 1}$ & $\mathbf{2 0 1 2}$ & $\mathbf{2 0 1 3}$ \\
\hline IRS & 23 & 22 & 24 & 17 & 14 & 10 & 10 & 10 & 13 & 7 \\
CRS & 9 & 10 & 8 & 12 & 19 & 15 & 7 & 13 & 10 & 14 \\
DRS & 1 & 1 & 1 & 4 & 0 & 8 & 16 & 10 & 10 & 12 \\
\hline Total & 33 & 33 & 33 & 33 & 33 & 33 & 33 & 33 & 33 & 33 \\
\hline
\end{tabular}

Information: CRS: Constant Return to Scale, IRS: Increasing Return to Scale, DRS: Decreasing Return to Scale.

decreasing. Therefore, the treatment that is applied to each indicator cannot be the same. Huang et al. (2013) suggested that inefficient DMUs are a result of operating below the optimal scale. The most appropriate option to increase efficiency is to increase the size of the DMUs. Meanwhile, inefficient DMUs are a result of operating above the optimal scale, the option that can be taken is to decrease the DMU size (decreasing firm size) (Krasachat \& Chimkul, 2009).

\section{CONCLUSION}

Data updates on cooperatives in Indonesia have been running regularly. The Ministry of Cooperatives and SMEs publish data on cooperatives annually, which includes the number of cooperatives, the number of members, and the financial aspects of the cooperatives. However, in several of these publications, data were still found to be very temporary and had not been updated with the latest time. In terms of efficiency, generally, cooperatives in several regions have not performed their activities efficiently, either because the activities that are running are not optimal (increasing the size of DMUs) or activities that have exceeded their optimal capacity (decreasing firm size).

Suggestions that can be offered through this study are: 1) The central government requires conducting consolidation with local governments and the cooperative movements. Data collection is conducted periodically through the lowest level, which is the primary cooperative. If the primary cooperative group has a secondary cooperative, the secondary cooperative can become the coordinator of the data collection of the primary cooperative. However, if there is no secondary cooperative, coordination of data collection can be performed directly by regional apparatus organizations (cooperative agency) in collaboration with the cooperative council in Indonesia at the regency/city level. From these levels, the data then collected to form a data set at the provincial level, until finally centered on the national level. 2) This study has limited the scope of efficiency which is measured relatively between the data on cooperatives in general in a province with data on cooperatives in general in 32 other provinces in Indonesia. Therefore, further research is required to be able to compare efficiency in Indonesia based on existing provinces using the latest data.

\section{REFERENCES}

Abidin, Z., and E. Endri. 2009. Kinerja efisiensi teknis bank pembangunan daerah: Pendekatan data envelopment analysis (DEA). Jurnal Akuntansi dan Keuangan 11(1): 21-29. https://doi.org/10.9744/jak.11.1.pp.21$\underline{29}$

Altman, M. 2015. Cooperative organizations as an engine of equitable rural economic development. Journal of CoOperative Organization and Management 3: 14-23. https://doi.org/10.1016/j.jcom.2015.02. $\underline{001}$

Ariyaratne, C. B., A. M. Featherstone, M. R. 
Langemeier, and D. G. Barton. 2000. Measuring $x$-efficiency and scale efficiency for a sample of agricultural cooperatives. Agricultural and Resource Economics Review 29(2): 198-207.

https://doi.org/10.1017/s10682805000 $\underline{05335}$

Budiasih, Y., Asriyal, and I. H. Mardika. 2019. Tingkat efisiensi koperasi di Kota Tangerang Selatan dengan pendekatan data envelopment analysis (DEA). Jurnal Penelitian Manajemen 1(2): 236-243.

https://doi.org/.1037//00332909.I26.1.78

Chen, T., C. B. Chen, and S. Y. Peng. 2008. Firm operation performance analysis using data envelopment analysis and balanced scorecard. International Journal of Productivity and Performance Management 57(7): 523539.

Huang, Z., Y. Fu, Q. Liang, Y. Song, and X. $\mathrm{Xu}$. 2013. The efficiency of agricultural marketing cooperatives in China's Zhejiang Province. Managerial and Decision Economics 34: 272-282. https://doi.org/10.1002/mde

Krasachat, W., and K. Chimkul, K. 2009. Performance measurement of agricultural cooperatives in Thailand: An accounting-based data envelopment analysis. Productivity, Efficiency, and Economic Growth in the Asia-Pacific Region: 255-266. https://doi.org/10.1007/978-3-79082072-0-12

Othman, A., N. Mansor, and F. Kari. 2014. Assessing the performance of cooperatives in Malaysia: an analysis of co-operative groups using a data envelopment analysis approach. Asia
Pacific Business Review 20(3): 484505.

https://doi.org/10.1080/13602381.2014 .933065

Retnowati, D. H. F. Manongga, and H. Sunarto. 2018. Prinsip-prinsip open government data studi kasus evaluasi keterbukaan informasi publik di Indonesia. Proceeding of Conference on Electrical Engineering, Telematics, Industrial Technology, and Creative Media: 25-29.

Sidauruk, R., and M. Hamdi, M. 2015. Mendorong pembentukan kebijakan dan implementasi data terbuka di Indonesia. Jakarta Selatan: Institute for Criminal Justice Reform.

Sirait, E. R. E. 2016. Implementasi teknologi big data di Lembaga Pemerintahan Indonesia. Jurnal Penelitian Pos dan Informatika 6(2): 113-136. https://doi.org/10.17933/jppi.2016.060 $\underline{201}$

Siregar, A. P., Jamhari, and L. R. Waluyati. 2016. Performance of village unit cooperatives in Yogyakarta Special Region: A data envelopment analysis approach. Ilmu Pertanian (Agricultural Science) 1(2): 67-73. https://doi.org/10.22146/ipas.10656

Wang, X., L. Sun, and Y. Zhang. 2012. The empirical study on operating efficiency of agricultural cooperatives in Langao. International Journal of Business and Management 7(17): 60-69. https://doi.org/10.5539/ijbm.v7n17p60 